\title{
From Toussaint to Tupac: The Black International since the Age of Revolution, edited by Michael 0. West, William G. Martin, and Fanon Che Wilkins
}

(Chapel Hill: University of North Carolina Press, 2009. 318 pp. Cloth, \$59.95. Paper, \$22.95.)

Reviewed by Michael E. Brandon

$\mathrm{n}$ the introduction to From Toussaint to Tupac, editors Michael West and William Martin claim that the "two dominant scholarly traditions, the metanarrative and the national narrative, have intellectually marginalized the black international" from Western academic discourse (1-2). West and Martin assert that generations of scholarship have facilitated a fragmented narrative of the global Black experience by isolating Blacks and their enduring struggles for equality to specific time periods and locales. Thus, From Toussaint to Tupac provides an important scholastic reorientation, a "black internationalist counternarrative" of culture and resistance within the African diaspora that transcends both time and place (2). Beginning with the Age of Revolution and concluding with the rise of hip hop culture, the collection of essays demonstrates that the Atlantic was not a barrier but a conduit for the ideological, cultural, and organizational links that have long sustained traditions of Black political radicalism and racial consciousness.

Part 1 of From Toussaint to Tupac, with essays by Sylvia Frey and by Michael West and William Martin, contends that modern Pan-Africanism is rooted in a rich history that stretches back to the Haitian Revolution. According to these scholars, the American and Haitian Revolutions, in conjunction with the Evangelical Revival, produced a revolutionary and revivalist tradition that gave birth to a nascent Pan-African ideology-a loose, though recognizable, worldview that served as the springboard to more formalized institutions like the Universal Negro Improvement Association and the Pan-African Congress. Furthermore, these scholars insist that the Haitian Revolution and the geographically diverse, post-revolutionary diaspora contributed to the con-

Michael E. Brandon is a Ph.D. candidate in history at the University of Florida. He researches the relationship between black migration, ghettoization, and politicization. His dissertation examines the origins of the Civil Rights movement through the careers of Congressmen Oscar S. De Priest and Arthur W. Mitchell.

Kalfou, Volume 1, Issue 1 (Spring 2014). (C) 2014 by the Regents of the University of California. ISSN 2151-4712 (print). ISSN 2372-0751 (online). http://dx.doi.org/10.15367/kf.v1i1.20. All rights reserved. 
struction of a subversive political tradition steeped in a steadfast, spiritual belief in Black liberation that permeated the Atlantic world.

Part 1 is emblematic of a crucial shift in scholarship on the Age of Revolution. Although the Enlightenment had a significant impact on the democratic fervor of the era, it is now conventional wisdom amongst scholars that such sociopolitical upheaval possessed limitations, particularly along the lines of race, gender, ethnicity, and economic status. Yet some scholars in the 1980s and 1990s, though acknowledging the exclusionary aspects of Enlightenment thought, insisted that whites on both sides of the Atlantic built an enduring framework for the marginalized to pursue universal emancipation. The essays by Frey and by West and Martin are representative of an emerging consensus on the revolutionary era, which vigorously argues that nascent Pan-Africanists in the Age of Revolution were themselves important agents in pursuing their liberation. This recognition of Black agency remarkably broadens the scholastic conceptions of the Enlightenment beyond former presumptions of its Eurocentricity, while also expanding the cast of characters in the revolutionary drama to include those who most acutely embodied the radical imperatives of revolutionary ideology.

From Toussaint to Tupac's first set of essays establishes that the Age of Revolution facilitated the growth of a subversive political tradition based on racial consciousness, while Part 2 explores how subsequent generations built an ideological and cultural network throughout the Atlantic world, as evidenced chiefly by Garveyism and the Pan-African Congress. Essays by Lara Putnam, Robert Vinson, and Hakim Adi reveal that in the first half of the twentieth century, an upsurge in Black consciousness was evident in the political mobilizations of communities throughout the Atlantic and beyond. Putnam focuses on the Caribbean, which produced an extraordinary number of scholar-activists whose voices and determination were vital to sustaining the revolutionary fervor of Black internationalists. Examining voluntary organizations, fraternal organizations, and periodicals like the Negro World, Putnam describes the process whereby Black West Indians developed a reform spirit based on collective civic engagement. Their efforts resulted in a reform-oriented culture that advocated political and economic empowerment and a race-conscious identity. Vinson's essay buttresses Putnam's focus on racially conscious civic engagement by examining the perennial power of spirituality and the revivalist tradition. Assessing South African Garveyism, Vinson argues that "Providential Design," which stressed "the 'redemption' of Africa through Christianity and commerce," catalyzed the development of racial consciousness (11). "Providential Design" influenced Blacks not only in South Africa, but also in the Americas, as a neo-Black "civilizing mission" promised a triumphant resuscitation of the African continent (11).

Owing to its class-based pretensions, the racial consciousness forged by Garvey-inspired civic engagement was challenged by the influence of a radical, 
political discourse born of the Bolsheviks' victorious revolution in Russia. Echoing Robin Kelley's pioneering work on Black communists in Alabama, Hakim Adi's essay "The Communist International and Black Liberation in the Interwar Years" argues that the support for Black liberation from the Communist International (Comintern) empowered African Americans at the grassroots by stressing self-determination and positioning Blacks for leadership at home and in the global fight for economic justice and social equality (156). As the Comintern and its tangled, though at times responsive, network of activists challenged both middle-class reform and Civil Rights organizations for a leadership position in the Black Freedom struggle, Black communists and their sympathizers broadened racial consciousness to include a crucial, class-based worldview-a perspective that believed Black liberation could not be achieved by integration into a flawed, exploitative system of global capitalism; revolutionary upheaval was necessary to address the plight of all workers, regardless of race or ethnicity.

The influence of Marxist discourse on Black consciousness is evident in Part 3 of From Toussaint to Tupac, which examines the Black Power era and its subsequent impact on the contemporary sociopolitical landscape. Although the American mainstream media often still portray activists of the late 1960s as stereotypical militants who eschewed nonviolence for the quixotic embrace of armed revolution, Black Power represented a substantive critique of structural socioeconomic inequality and liberalism's shortcomings. From Toussaint to Tupac fashions Black Power activists as a new generation of Black internationals-a cohort of radicals committed to an agenda that can be traced to the Haitian Revolution's bloody battlefields. Brian Meeks's contribution demonstrates that Black Power ideology, premised on solidarity and the cultural expression of an empowered Black identity, was not merely an urban, American phenomenon. In fact, in "The Rise and Fall of Caribbean Black Power," Meeks claims African American activists in the late 1960s had compatriots throughout the Black Atlantic, as evidenced by Caribbean radicalism, Walter Rodney's courageous activism, and the 1970 uprising in Trinidad and Tobago.

The Black Panthers, SNCC militants, and other Black Power advocates promoted anti-colonialism (an issue considered toxic by most mainstream Civil Rights organizations in the climate of the Cold War) and stressed the travails of urban poverty. More importantly, as Robyn Spencer argues in her essay, these activists were echoing the voices of previous generations of Black internationalists. Spencer notes that after "black internationalism in the United States suffered serious reversals" during the early phases of the Cold War in the 1950s and 1960s, the Black Panthers-among other proponents of Black Power-were actually central to reviving the radical internationalist tradition (217).

Although much of the international Black tradition is underrepresented in contemporary politics, and its passionate, lingering voices are often muted by 
the mainstream media, Marc Perry's piece claims that "hip hop's rise as a global cultural phenomenon" has filled an important void. Perry notes that from America to the Caribbean, Brazil, and beyond, marginalized youths have used the "expressive elements of music, verbal lyricism, dance, graffiti art, and fashion" to declare a sense of self that is personal, while also cultural and political (232). Perry also argues that "nationally transcendent modes of black diasporic identification prove strategic in challenging local conditions of racial oppression," while continuing to be "responsive to the ways [in which] global processes are increasingly reshaping such conditions" (255).

Though the ever-present criticism of rap music for its misogynistic themes, glamorization of violence, and vaunting of extravagant wealth may merit debate, Perry masterfully succeeds in demonstrating that hip hop culture is a positive step toward identity construction - an individual route that ultimately forges a collective, globe-spanning march toward the well-trodden paths of Black internationalism. Removed from the negative archetypes frequently presented by critics in the mainstream media-and dissociated from rapacious corporations whose affluence and power is at times contingent upon the propagation of demeaning stereotypes-hip hop has given power to a formerly invisible, dispossessed generation whose voices continue to echo the long tradition of the Black internationalist movement.

Michael West and William Martin's stirring introduction precedes a fascinating, well-argued collection of essays whose breadth, both temporally and geographically, issues a dramatic call to scholars of the global Black Freedom struggle. From Toussaint to Tupac presents a challenge, an opportunity to recognize international connections and to truly capture the herculean efforts of a multigenerational, international call for universal liberation-a struggle that remains unfinished. 